\title{
Modulatory effect of selected phenolic acids on enzyme activities of purinergic signaling
}

\author{
Adedayo O. Ademiluyi ${ }^{a^{*}}$, Taiwo A. Adeyeye ${ }^{a}$, Opeyemi B. Ogunsuyi ${ }^{\mathrm{a}, \mathrm{b}}$, \\ Damilola M. Olatunde ${ }^{\mathrm{a}}$ and Ganiyu $\mathrm{Oboh}^{\mathrm{a}}$
}

\begin{abstract}
aDepartment of Biochemistry, Federal University of Technology, P.M.B. 704, Akure. Nigeria
${ }^{b}$ Department of Biomedical Technology, Federal University of Technology, P.M.B. 704, Akure. Nigeria

*Corresponding author: Adedayo O. Ademiluyi, Department of Biochemistry, Federal University of Technology, P.M.B. 704, Akure. Nigeria. Tel: +234(0)8038044248; E-mail: aoademiluyi@futa.edu.ng, ademiluyidayo@yahoo.co.uk

DOI: $10.31665 / J F B .2019 .7199$

Received: May 28, 2019; Revised received \& accepted: September 29, 2019

Citation: Ademiluyi, A.O., Adeyeye, T.A., Ogunsuyi, O.B., Olatunde, D.M., and Oboh, G. (2019). Modulatory effect of selected phenolic acids on enzyme activities of purinergic signaling. J. Food Bioact. 7: 56-62.
\end{abstract}

\begin{abstract}
The antioxidant activities and effects of selected phenolic acids (ferulic, caffeic, $p$-coumaric and chlorogenic acids) on enzymes (ATPdase, ecto- $5^{\prime}$ nucleotidase, phosphodiesterase- $5^{\prime}$ and $\mathrm{Na}^{+} / \mathrm{K}^{+}$ATPase) of the purinergic signalling in isolated rat brain were assessed. The antioxidant properties as typified by the DPPH and ABTS radical scavenging ability as well as inhibition of thiobarbituric acid reactive substances (TBARS) production in isolated rat brain revealed that chlorogenic acid had the highest antioxidant effect. Furthermore, ferulic acid had the highest $\mathrm{Na}^{+} /$ $\mathrm{K}^{+}$-ATPase $\left(\mathrm{IC}_{50}=3.48 \mu \mathrm{M}\right)$ stimulatory activity, as well as the highest ecto-5' nucleotidase $\left(\mathrm{IC}_{50}=6.22 \mu \mathrm{M}\right)$ inhibitory activity. In addition, chlorogenic acid had the highest phosphodiesterase- $5^{\prime}\left(\mathrm{IC}_{50}=21.03 \mu \mathrm{M}\right)$ inhibitory activity while $p$-coumaric acid caused the highest inhibition of ATPdase $\left(\mathrm{IC}_{50}=17.56 \mu \mathrm{M}\right)$ activity. This study revealed that the phenolic acids altered critical enzymes of the purinergic signaling in addition to their antioxidant properties thus, suggesting their possible neuromodulatory effects.
\end{abstract}

Keywords: Purinergic system; Phenolic acids; Neuromodulation; Oxidative stress; Antioxidants.

\section{Introduction}

The role of purinergic system in neuronal function has been well established and studied (Ademiluyi et al., 2016). Consequently, interest has been directed towards characterization of purinergic signalling in different regions of the brain and spinal cord. Various purinergic-receptor subtypes have been shown to be widely distributed throughout the CNS, being present in neurons and glia (Burnstock, 2007). It is now well established that ATP both acts as a fast excitatory neurotransmitter and has potent long-term (trophic) role in cell proliferation, growth and development, and in disease and cytotoxicity (Zimmermann et al., 2006).

The purinergic signalling system is a ubiquitous extracellular communication channel mediated by ATP and its extracellular breakdown product adenosine as well as enzymes such as nu- cleoside triphosphate diphosphohydrolases, ecto-5' nucleotidase and $\mathrm{Na}^{+} / \mathrm{K}^{+}$ATPase which have been implicated in neurodegenerative diseases. Ecto-5' nucleotidase is a magnesium-dependent glycoprotein which functions in the hydrolysis of adenosine monophosphate to the nucleoside adenosine that consequently activate the inorganic phosphate $(\mathrm{Pi})$ adenosine receptors (Sinha et al., 2016). $\mathrm{Na}^{+} / \mathrm{K}^{+}$-ATPase is a crucial enzyme responsible for maintaining the ionic gradient necessary for neuronal excitability. It is present at high concentrations in brain cellular membranes, consuming about $40-50 \%$ of the ATP generated in this tissue, $\mathrm{Na}^{+} / \mathrm{K}^{+}$-ATPase activity is decreased in various chronic neurodegenerative disorders.

Nucleoside triphosphate diphosphohydrolases (EC 3.6.1.5, NTPDases) are well characterized ectoenzymes in the central nervous system. The phosphodiesterases (PDEs) are a super family of enzymes that catalyze the hydrolysis of the nucleotide 
monophosphates, cyclic adenosine monophosphate (cAMP), and cyclic guanosine monophosphate (cGMP) to the corresponding nucleoside monophosphates. Several of the PDEs have already been identified and characterized, including PDE-5, PDE-6, PDE-8, PDE-9, PDE-10, and PDE-11, to name a few (Soderling et al., 1999; Yuasa et al., 2000). Moreover, the NTPDase family, composed of the eight members NTPDase 1 to 8 , is involved in controlling nucleotide and nucleoside concentrations, acting to regulate purinergic neurotransmission (Rico et al., 2008) of which E-NTPDase 1, 2, 3 and 8 are extracellular. NTPDase 1 hydrolyses ATP directly to AMP, and UTP to UDP, whereas NTPDase 2 converts ATP to ADP. Immunohistochemical studies revealed that this enzyme is strongly associated with axon-like neuronal structures in the brain, where it may act as a main regulator of extracellular ATP levels.

Phenolic compounds are a large class of plant secondary metabolites, showing a diversity of structures, from rather simple structures, e.g. phenolic acids, through polyphenols such as flavonoids, that comprise several groups, to polymeric compounds based on these different classes. Phenolic compounds are known to be responsible for the free radical scavenging and antioxidant activities of plants; they possess many biological effects, mainly attributed to their antioxidant activities in scavenging free radicals, inhibiting peroxides and chelating transition metals and can protect against neurodegenerative diseases, (Adefegha et al., 2018; Shahidi and Yeo 2018). Phenolic compounds have the potential to act against oxidative damage; therefore play a protective role in living organism. Because of their antioxidant activities, they are widely used in processed foods as a natural antioxidant. This study investigated the effects of some phenolic acids such as; caffeic, ferulic, $p$-coumaric and chlorogenic acid on some enzymes of the purinergic system in isolated rat brain homogenate in vitro. These phenolic acids are ubiquitous in plant foods such as caffeic and chlorogenic acid from coffee (Oboh et al., 2013; Celli and de Camargo 2019), ferrulic acid from millet and whole wheat (Gawlik-Dziki et al., 2017; Kumari et al., 2019) and $p$-coumaric acid from grains (wheat, rice, and corn) and fruits (apple, pears and grapes (Pei et al., 2016; Shahidi et al., 2019).

\section{Materials and methods}

\subsection{Sample preparation}

Based on the physiological plasma peak concentration of phenolic acids as described by Ishisaka et al. (2011), the concentrations of the phenolic acids (caffeic acid, ferulic acid, chlorogenic acid, $p$-coumaric acid) used in this study were between $50-1,000 \mu \mathrm{M}$ (aqueous solutions).

\subsection{Chemicals and reagents}

Chemicals such as caffeic acid, ferulic acid, chlorogenic acid, $p$-coumaric acid, adenosine triphosphate (ATP), adenosine monophosphate (AMP), ouabain, ammonium molybdate, thiobarbituric acid, (TBA), phosphate buffer of different molarity, sodium hydroxide, benzene, and 5,5'-dithio-bis(2-nitrobenzoic acid) were purchased from Sigma-Aldrich, ChemieGmH (Steinheim, Germany). Acetic acid was procured from BDH Chemical Ltd., (Poole, England). Except otherwise stated, all other chemicals and reagents are of analytical grade while the water was glass distilled.

\section{3. $D P P H$ radical scavenging ability}

The scavenging ability of the phenolic acids against DPPH (1,1-diphenyl-2 picrylhydrazyl) radical was evaluated as described by Gyamfi et al. (1999). Briefly, appropriate dilution (50-1,000 $\mu \mathrm{M})$ of the phenolic acid $(1 \mathrm{~mL})$ was mixed with $1 \mathrm{~mL}, 0.4 \mathrm{mM} \mathrm{DPPH}$ in methanolic solution, the mixture was left in the dark for $30 \mathrm{~min}$ and the absorbance was taken at $516 \mathrm{~nm}$. The DPPH free radical scavenging ability was subsequently calculated as percentage of control.

\subsection{ABTS radical scavenging ability}

The ability of the phenolic acids to scavenge 2,2'-azino-bis(3ethylbenzthiazoline-6-sulphonic acid (ABTS) radical cation was determined according to the method of Re et al. (1999). The $\mathrm{ABTS}^{+}$was generated by reacting an aqueous solution of ABTS $(7 \mathrm{mmol} / \mathrm{L})$ with $\mathrm{K}_{2} \mathrm{~S}_{2} \mathrm{O}_{8}(2.45 \mathrm{mmol} / \mathrm{L}$, final concentration) in the dark for $16 \mathrm{~h}$ and adjusting the absorbance at $734 \mathrm{~nm}$ to 0.700 with ethanol. Thereafter, $0.2 \mathrm{~mL}$ of appropriate dilution $(0.05-13$ $\mathrm{mM}$ ) of the phenolic acid was added to $2.0 \mathrm{~mL}$ of ABTS ${ }^{+}$solution and the absorbance was read at $734 \mathrm{~nm}$ after $15 \mathrm{~min}$. The Trolox equivalent antioxidant capacity was subsequently calculated using Trolox as the standard.

\subsection{Lipid peroxidation and thiobarbibutric acid reactions}

The lipid peroxidation assay was carried out using the modified method of Ohkawa et al. (1979). Briefly, $100 \mu \mathrm{L}$ of rat brain homogenate fraction was mixed with a reaction mixture containing $30 \mu \mathrm{L}$ of Tris- $\mathrm{HCl}$ buffer $(0.1 \mathrm{M}, \mathrm{pH} 7.4)$, phenolic acid solutions $(50 \mu \mathrm{L})$ and $30 \mu \mathrm{L}$ of $250 \mu \mathrm{M}$ of freshly prepared $\mathrm{FeSO}_{4}$. The volume was made up to $300 \mu \mathrm{L}$ with distilled water before incubation at $37^{\circ} \mathrm{C}$ for $1 \mathrm{~h}$. Thereafter, $300 \mu \mathrm{L}$ of $8.1 \%$ sodium dodecyl sulfate (SDS) was added to the reaction mixture and was followed by addition of $600 \mu \mathrm{L}$ of acetic acid/ $\mathrm{HCl}(\mathrm{pH} 3.4)$ mixture and 600 $\mu \mathrm{L}$ of $0.8 \%$ TBA (thiobarbituric acid). This mixture was incubated at $100{ }^{\circ} \mathrm{C}$ for $1 \mathrm{~h}$. TBARS (thiobarbituric acid reactive substances) produced were measured at $532 \mathrm{~nm}$ and expressed as percentage of control.

\section{6. $\mathrm{Na}^{+} / \mathrm{K}^{+}$-ATPase assay}

The $\mathrm{Na}^{+} / \mathrm{K}^{+}$-ATPase activity was measured in whole rat brain homogenate and incubated with the selected phenolic acids as described by Wyse et al. (2000). The assay mixture consisted of 50 $\mu \mathrm{L}$ of $\mathrm{Na}^{+} / \mathrm{K}^{+}$-ATPase substrate buffer ( $\mathrm{pH}$ 7.4) (containing in $\mathrm{mM}$, 30 Tris- $\mathrm{HCl}, 0.1 \mathrm{EDTA}, 50 \mathrm{NaCl}, 5 \mathrm{KCl}$, and $\left.6 \mathrm{MgCl}_{2}\right), 50 \mu \mathrm{L}$ of each of the selected phenolics $(0.05-13 \mathrm{mM}), 50 \mu \mathrm{L}$ of supernatant ( $50 \mu \mathrm{g}$ of protein) in the presence or absence of $50 \mu \mathrm{L}$ of ouabain ( $1 \mathrm{mM}$ ), in a final volume of $200 \mu \mathrm{L}$. The reaction was initiated by the addition of $50 \mu \mathrm{L}$ adenosine triphosphate (ATP) to a final concentration of $3 \mathrm{mM}$. After incubating for $30 \mathrm{~min}$ at $37^{\circ} \mathrm{C}$, the reaction was terminated by the addition of $70 \mu \mathrm{L}$ of $50 \%(\mathrm{w} / \mathrm{v})$ trichloroacetic acid (TCA). The amount of inorganic phosphate (Pi) released was quantified as described by Fiske and Subbarow (1925) using a reaction mixture that contained $100 \mu \mathrm{L}$ of ammonium molybdate $(50 \mathrm{mM}), 40 \mu \mathrm{L}$ of reaction mixture from first grid and $10 \mu \mathrm{L}$ of ascorbic acid $(8 \%)$. The enzyme activity was expressed in nmol. of $\mathrm{Pi} / \mathrm{mg}$ of protein $/ \mathrm{min}$. 


\subsection{ATPDase assay}

The effect of the phenolic acids on ATPDase activity was determined as described by Schetinger et al. (2000), with slight modification. The assay mixture consisted of $5 \mathrm{mM} \mathrm{CaCl}_{2}, 5 \mathrm{mM} \mathrm{KCl}$, $0.1 \mathrm{mM}$ EDTA, and $50 \mathrm{mM}$ Tris- $\mathrm{HCl}$ buffer ( $\mathrm{pH} 7.4$ ) in a final reaction volume of $200 \mu \mathrm{L}$. Twenty microliters of the supernatant (enzyme preparation) with protein content of $8-12 \mu \mathrm{g}$ were added to the reaction mixture and pre-incubated at $37^{\circ} \mathrm{C}$ for $10 \mathrm{~min}$. The reaction was initiated by the addition of ATP as substrate to obtain a final concentration of $1.0 \mathrm{mM}$, followed by incubation for $20 \mathrm{~min}$. The reaction was stopped by the addition of $200 \mu \mathrm{L}$ of $10 \%$ trichloroacetic acid (TCA) to obtain a final concentration of $5 \%$ and the tubes were chilled on ice for $10 \mathrm{~min}$. The released inorganic phosphate $(\mathrm{Pi})$ was assayed by the method of Fiske and Subbarow (1925) using ascorbic acid as colorimetric reagent and $\mathrm{KH}_{2} \mathrm{PO}_{4}$ as standard. Enzyme activity was expressed as expressed in $\mathrm{nmol}$. of $\mathrm{Pi} / \mathrm{mg}$ of protein $/ \mathrm{min}$.

\subsection{Phosphodiesterase type 5 (PDE-5) assay}

The effect of the phenolic acids on phosphodiesterase-5' activity was tested using the method of Kelly and Butler (1977) with slight modification. The substrate, $p$-nitrophenylphenylphosphonate, (55.84 $\mathrm{mg}$ ) was dissolved in $20 \mathrm{~mL}$ of Tris buffer $\mathrm{pH} 7.4$ to produce $5 \mathrm{mM}$ working solution. The substrate, enzyme, and the phenolic solution were incubated separately in a water bath at $37^{\circ} \mathrm{C}$ for $10 \mathrm{~min}$ to equilibrate. Different concentration of the phenolic acids was mixed with $100 \mu \mathrm{L}$ of the enzyme and incubated in water bath maintained at $37{ }^{\circ} \mathrm{C}$. Thereafter, $1 \mathrm{~mL}$ of the substrate was subsequently added to the mixture and was left to stand for 30 seconds. Change in absorbance after $5 \mathrm{~min}$ at $400 \mathrm{~nm}$ was taken as a function of the enzyme activity.

\subsection{Ecto-5' nucleotidase assay}

Ecto- $5^{\prime}$ nucleotidase activity was determined in whole rat brain homogenate as described by Heymann et al. (1984). The assay mixture consisted of appropriate dilutions of the phenolic acids,

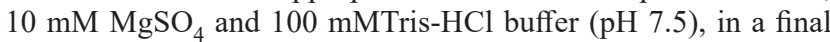
volume of $200 \mu \mathrm{L}$. Twenty microliters of tissue $(8-12 \mu \mathrm{g}$ of protein) were added to the reaction mixture and pre-incubated at 37 ${ }^{\circ} \mathrm{C}$ for $10 \mathrm{~min}$. The reaction was initiated by the addition of AMP to a final concentration of $2.0 \mathrm{mM}$ and proceeded for $20 \mathrm{~min}$. In all cases, reaction was stopped by the addition of $200 \mu \mathrm{L}$ of $10 \%$ trichloroacetic acid (TCA) to obtain a final concentration of $5 \%$ and the tubes were chilled on ice for $10 \mathrm{~min}$. The released inorganic phosphate (Pi) was assayed by the method of Fiske and Subbarow (1925) using ascorbic acid as colorimetric reagent and

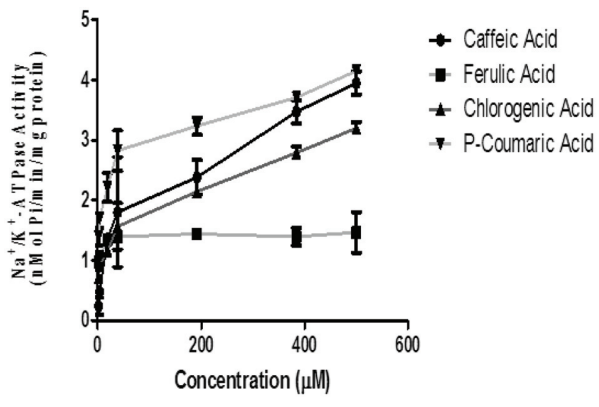

Figure 1. Effect of the phenolic acids (caffeic, ferulic, chlorogenic and p-coumaric acid) on $\mathrm{Na}^{+} / \mathrm{K}^{+}$-ATPase Activity in isolated rat brain. Values represent mean \pm SD of triplicate experimental readings.

$\mathrm{KH}_{2} \mathrm{PO}_{4}$ as standard. Enzyme activity was expressed as expressed in $\mathrm{nmol}$. of $\mathrm{Pi} / \mathrm{mg}$ of protein $/ \mathrm{min}$.

\subsection{0. $I C_{50}$}

The concentration of the phenolic acids causing 50\% inhibition of ATPDase, phosphodiesterase-5' and ecto-5' nucleotidase activities as well as stimulation of $\mathrm{Na}^{+} / \mathrm{K}^{+}$-ATPase activity $\left(\mathrm{IC}_{50}\right)$ was calculated by nonlinear regression analysis.

\subsection{Data analysis}

The results of triplicate experimental readings were pooled and expressed as mean \pm standard deviation (S.D.). Student t-test, one-way analysis of variance (ANOVA) and least significance difference (LSD) were carried out. Significance was accepted at $p \leq$ 0.05 .

\section{Results and discussion}

\subsection{Effects of phenolic acids on $\mathrm{Na}^{+} / \mathrm{K}^{+}$-ATPase activity in rat brain homogenate}

Results from the assessment of the effects of phenolic acids on $\mathrm{Na}^{+} / \mathrm{K}^{+}$-ATPase activity revealed that the phenolic acids stimulate $\mathrm{Na}^{+} / \mathrm{K}^{+}$-ATPase activity in rat brain homogenate in a concentration dependent manner (Figure 1 and Table 1). The sodium-potassium-activated adenosine triphosphatase $\left(\mathrm{Na}^{+} / \mathrm{K}^{+}\right.$-ATPase; sodium pump; EC 3.6.1.37) is a plasma membrane-associated protein complex that directly or indirectly controls essential cellular functions which include but not limited to free calcium concentration, and membrane potential. By coupling the energy released in the

Table 1. $\mathrm{IC}_{50}$ values $(\mu \mathrm{M})$ for the inhibitory effect of selected phenolic acids (caffeic, ferulic, chlorogenic and $p$-coumaric acids) on $\mathrm{Na}^{+} / \mathrm{K}^{+}$-ATPase, ATPdase, Ecto-5'nucleotidase and phosphodiesterase-5'activities in isolated rat brain homogenates

\begin{tabular}{lllll}
\hline Enzyme activity & Caffeic Acid & Ferulic Acid & Chlorogenic Acid & $p$-coumaric Acid \\
\hline $\mathrm{Na}^{+} / \mathrm{K}^{+}-$ATPase & $75.57 \pm 0.22^{\mathrm{c}}$ & $3.48 \pm 0.09^{\mathrm{a}}$ & $253.9 \pm 0.14^{\mathrm{d}}$ & $48.59 \pm 0.15^{\mathrm{b}}$ \\
ATPDase & $346.9 \pm 0.03^{\mathrm{d}}$ & $27.48 \pm 0.02^{\mathrm{c}}$ & $18.37 \pm 0.07^{\mathrm{b}}$ & $17.56 \pm 0.04^{\mathrm{a}}$ \\
Ecto-5' nucleotidase & $8.25 \pm 4.13^{\mathrm{a}}$ & $6.22 \pm 1.76^{\mathrm{a}, \mathrm{b}}$ & $12.48 \pm 3.26^{\mathrm{b}}$ & $35.31 \pm 1.59^{\mathrm{c}}$ \\
Phosphodiesterase-5' & $35.73 \pm 0.11^{\mathrm{b}}$ & $400.3 \pm 0.05^{\mathrm{d}}$ & $21.03 \pm 0.21^{\mathrm{a}}$ & $128.4 \pm 0.08^{\mathrm{c}}$ \\
\hline
\end{tabular}

Values represent means \pm standard deviation $(n=3)$. ${ }^{a-d}$ Mean values with the same superscript letter on the same row are not significantly different $(p>0.05)$. 


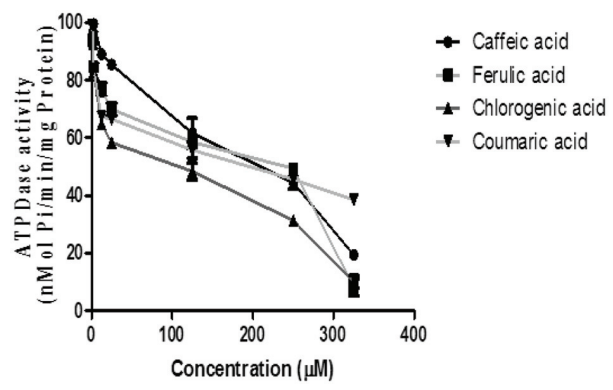

Figure 2. Effect of the phenolic acids (caffeic, ferulic, chlorogenic and $p$ coumaric acid) on ATPDase activity in isolated rat brain. Values represent mean \pm SD of triplicate experimental readings.

intracellular hydrolysis of ATP to the export of three intracellular $\mathrm{Na}^{+}$ions and the import of two extracellular $\mathrm{K}^{+}$ions, $\mathrm{Na}^{+} / \mathrm{K}^{+}$ electrochemical gradient which is essential for the regulation of cell volume action potential of muscle and nerve is maintained (de Lores Arnaiz and Ordieres 2014). Hence, proper and coordinated regulation of this enzyme is crucial to prevention of diseases. The phenolic acid thus binds to and enhance the activity of this enzyme in the brain.

The $\mathrm{IC}_{50}$ (Table 1) revealed that these phenolic acids exerted various degrees of stimulatory effects with respect to their type and concentration. Ferulic acid caused the highest stimulatory effect while chlorogenic acid caused the least. $\mathrm{Na}^{+} / \mathrm{K}^{+}$-ATPase is a crucial enzyme responsible for maintaining the ionic gradient necessary for neuronal excitability. It is present at high concentrations in brain cellular membranes, consuming about $40-50 \%$ of the ATP generated in the tissue (de Lores Arnaiz and Ordieres 2014). With regard to the importance of this enzyme for the proper functioning of cells and tissues and especially in nerve cells, this enzyme regulates the entry of $\mathrm{K}^{+}$with the exit of $\mathrm{Na}^{+}$from cells, being responsible for $\mathrm{Na}^{+} / \mathrm{K}^{+}$equilibrium maintenance through neuronal membranes. Hence, the observed stimulatory effect of the phenolic acids on $\mathrm{Na}^{+} / \mathrm{K}^{+}$-ATPase activity could be beneficial to the proper functioning of this critical membrane bond enzymes system and for the maintenance of cellular integrity (Jorgensen and Pedersen, 2001). Studies have shown that $\mathrm{Na}^{+} / \mathrm{K}^{+}$activity in aged rat brains is significantly lower than that at other stages of brain development. This may be related to the depression of neuronal excitability with impairment of cognitive functions being advanced (KoçakToker et al., 2002). Thus, foods rich in phenolic acids with $\mathrm{Na}^{+} /$ $\mathrm{K}^{+}$-ATPase stimulatory property could help counteract the effect of age-induced depression of neuronal excitability.

\subsection{Effects of phenolic acids on nucleoside triphosphate diphos- phohydrolases (ATPDase) activity in rat brain homogenate}

The ATPDase inhibitory ability of the phenolic acids in rat brain homogenate revealed that $p$-coumaric acid $\left(\mathrm{IC}_{50}=17.56 \mu \mathrm{M}\right)$ had the highest inhibitory activity with caffeic acid having the least (Figure 2 and Table 1). ATPDase enzyme belongs to a class of Nucleoside triphosphate diphosphohydrolases (EC 3.6.1.5, NTPDases) which hydrolyses ATP to ADP and consequently to AMP. Extracellular nucleotides and nucleosides are signaling molecules acting in all tissues and organs, including the central nervous system (CNS). A wide variety of effects, exerted by ecto-purines, requires that their levels and ATP in particular, must be precisely controlled. Under physiological conditions, concentration of ecto-purines is regulated by a complex cascade of ecto-enzymes, including ecto-
NTPDases (nucleosidetriphosphate diphosphohydrolases), ectoNPPs (nucleotide pyrophosphohydrolases/phosphodiesterases), ecto-alkaline phosphatases, and ecto-5' nucleotidase. The ectonucleosidase are involved in the breakdown of released ATP into ADP, AMP, adenosine, inosine and hypoxanthine (Zimmermann, 2006). Disturbances in the elements of purinergic pathway within the CNS underline the induction and amplification of several neurological pathologies.

As observed in the study, an inhibitory effect of the ATPDase was observed in the presence of the phenolic acids with $p$-coumaric acid having the highest inhibitory activity. This suggests modulatory effect of this enzyme by the phenolic acids. Previous study revealed that this enzyme is strongly associated with axon-like neuronal structures in the brain, where it may act as a main regulator of extracellular ATP levels (Sebastián-Serrano et al., 2018). In the nervous system, purines are important neuromodulators, acting at pre- and post-synaptic sites. Consequently, ATPDase may play an indirect role in the modulation of nucleotide- and nucleosidemediated processes (Sebastián-Serrano et al., 2018). The inhibition of ATPDase-like activity can impair the hydrolysis of the neurotransmitter ATP and, consequently, higher concetrations of ATP and other purine nucleotides accumulates in the extracellular space and is afforded more time of exposure and interaction with the purinoreceptors, this could promote an excessive activation of all P2 purinoreceptors, consequently altering purinergic neurotransmission. The high extracellular ATP concentration activating specific receptors ensures continuous twitching of the nerve fibres and the propagation of inflammatory processes; a process which is involved in a variety of CNS morbidities which includes brain injury and ischemia, neurodegenerative diseases involving neuroimmune and neuro-inflammatory reactions, as well as neuropathic pain and migraine (Burnstock, 2007).

It has been acknowledged that the size and the chemical structure and composition of compounds are usually some of the determining factors for their inhibitory effects (Berlin et al., 2006). Phenolics are a class of polyphenolic compounds which have been suggested to modulate several critical enzyme systems and cascades that are directly involved in several biological processes (Crozier et al., 2009). Some studies have demonstrated the modulatory effects of some polyphenols on the purinergic system as a function of their health promoting effect (Crozier et al., 2009). Phenolic carbonyl compounds tend to interact strongly with proteins, nucleic acids, or related biological molecules, which significantly inhibited the protein functions, DNA duplication, or even loss of cellular activity (Cilliers and Singleton, 1990). Berlin et al. (2006) also showed that the smallest phenolics often possesses the ability to assess the active sites of enzyme domains and more easily serve as more potent inhibitors of ATPDase when compared to the large polymerized phenolics with high molecular weight. Hence, $p$-coumaric acid with its higher inhibitory activity compared to other phenolics is a function of its small size and chemical composition.

\subsection{Effects of phenolic acids on ecto-5' nucleotidase activity in rat brain homogenate}

Assessment of the inhibitory effects of phenolic acids on the ecto$5^{\prime}$ nucleotidase activity revealed that phenolic acid inhibited the enzyme activity in a concentration dependent manner (0.05-13 $\mathrm{mM}$ ). Ecto-5' nucleotidase (e5NT) belongs to the family of metallophosphoesterases, which hydrolyses AMP to adenosine, and is a regulator of the adenosine signaling pathway (Zimmermann et al., 2006). One of the more obvious roles of the e5NT is the puriner- 


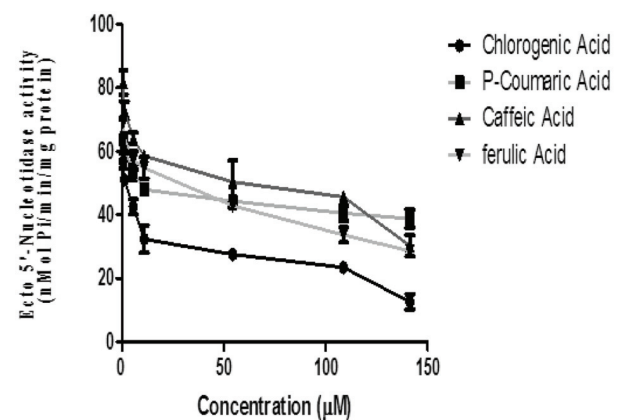

Figure 3. Effect of the phenolic acids (caffeic, ferulic, chlorogenic and $p$ coumaric acid) on ecto-5' nucleotidase activity in isolated rat brain. Values represent mean \pm SD of triplicate experimental readings.

gic recycling. This signaling involves the conversion of AMP into adenosine and inorganic phosphate ( $\mathrm{Pi}$ ), which allows nucleosides produced extracellular to be transported into cells; this could be recycled into AMP and subsequently converted into ATP which can later be released into the synaptic cleft (Goding, 2000).

The observed inhibitory effect of the phenolic acids on rat brain e5NT activity is a measure of their possible modulatory effect. The inhibition of $5^{\prime}$-nucleotidase could influence adenosine levels in the extracellular space favouring increased adenosine pool and an increased purine salvaging ability and perhaps a down-regulation of P1 purinoreceptors. Adenosine is a neuromodulator (normally inhibitory) in the central nervous system and participates in many metabolic and homeostatic cellular controls (Guieu et al., 1998). All phenolics inhibited this enzyme in a concentration dependent manner with ferulic acid $\left(\mathrm{IC}_{50}=6.22 \mu \mathrm{M}\right)$ having the significant $(p<0.05)$ highest inhibition of ecto-5' nucleotidase activity, while $p$-coumaric acid $\left(\mathrm{IC}_{50}=35.31 \mu \mathrm{M}\right)$ had the least (Figure 3 and Table 1).

\subsection{Effects of phenolic acids on phosphodiesterase-5' activity in rat brain homogenate}

The effect of phenolic acids on phosphodiesterase- $5^{\prime}$ activity revealed that chlorogenic acid $\left(\mathrm{IC}_{50}=21.03 \mu \mathrm{M}\right)$ had the highest inhibitory activity than caffeic acid $\left(\mathrm{IC}_{50}=35.73 \mu \mathrm{M}\right)$, $p$-coumaric acid $\left(\mathrm{IC}_{50}=128.4 \mu \mathrm{M}\right)$ with ferulic acid $\left(\mathrm{IC}_{50}=400.3 \mu \mathrm{M}\right)$ having the least inhibition of phosphodiesterase- 5 ' activity in vitro (Figure 4 and Table 1).

The phosphodiesterases (PDEs) are a super family of enzymes that catalyze the hydrolysis of the nucleotide monophosphates, cyclic adenosine monophosphate (cAMP), and cyclic guano-

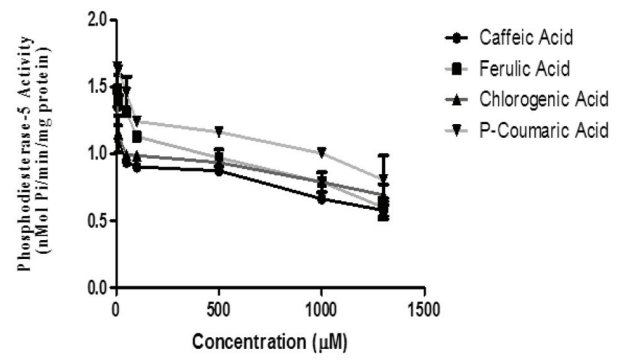

Figure 4. Effect of the phenolic acids (caffeic, ferulic, chlorogenic and $p$ coumaric acid) on phosphodiesterase-5-activity in isolated rat brain. Values represent mean \pm SD of triplicate experimental reading.

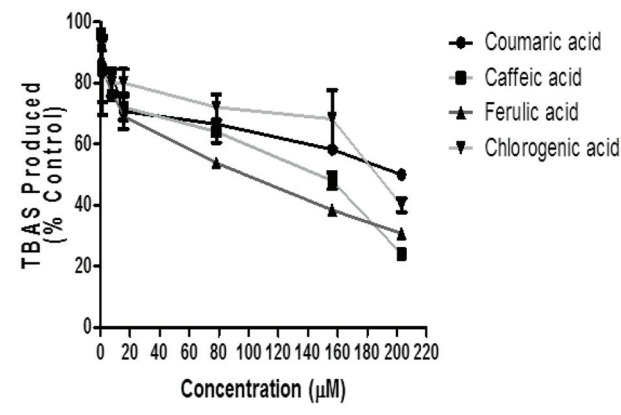

Figure 5. Inhibition of $\mathrm{Fe}^{2+}$ induced TBARS Production in rat's brain by phenolic acids (caffeic, ferulic, chlorogenic and $p$-coumaric acid). Values represent mean \pm SD of triplicate experimental reading.

sine monophosphate (cGMP) to the corresponding nucleoside monophosphates. . PDE-5 is expressed in various tissues of the body including the brain where its major function has been specific in catalysing the hydrolysis of cGMP (Reffelman et al., 2003; Senzaki et al., 2001). Studies have hypothesized that blocking the action of PDE-5 might result in increased intracellular levels and prolonged action of cGMP, which is a nitric oxide (NO) donor and potent vasodilator. Previous studies have reported that inhibition of PDE-5 improved memory (Prickaerts et al., 2002; Rutten et al., 2005) and counteracts spatial learning impairment induced by NOS inhibition (Devan et al., 2006). PDE inhibitors have been proposed to be employed as memory enhancers (Blokland et al., 2006; Rutten et al., 2007). Hence, these phenolic acids could be important dietary components with health promoting effect. Thus, inhibitors of PDE-5 such as the phenolic acids might be an alternative and perhaps more suitable for developing drugs targeted to CNS and memory (Puzzo et al., 2009).

\subsection{Effects of phenolic acids on antioxidant status in rat brain homogenate}

The incubation of rat's brain homogenates in the presence of $\mathrm{Fe}^{2+}$ caused a significant increase $(p<0.05)$ in the TBARS content $(96.15 \%)$. The phenolic acids inhibited TBARS production in a concentration-dependent manner (Figure 5 and Table 2). However, chlorogenic acid has the highest inhibitory ability $\left(\mathrm{IC}_{50}=7.54 \mu \mathrm{M}\right)$ and ferulic acid had the least $\left(\mathrm{IC}_{50}=81.38 \mu \mathrm{M}\right)$. Similarly, chlorogenic acid $\left(\mathrm{IC}_{50}=10.33 \mu \mathrm{M}\right)$ had significantly higher $(p<0.05)$ DPPH scavenging ability and caffeic acid $\left(\mathrm{IC}_{50}=91.73 \mu \mathrm{M}\right)$ had the least. Furthermore, chlorogenic acid $\left(\mathrm{IC}_{50}=7.21 \mu \mathrm{M}\right)$ showed significantly higher $(\mathrm{p}<0.05)$ scavenging ability towards ABTS radical cation while $p$-coumaric acid $\left(\mathrm{IC}_{50}=63.07 \mu \mathrm{M}\right)$ showed the lowest scavenging activity (Table 2 ).

Oxidative stress plays a major role in aging, and is associated with several diseases including neuropathological conditions (Singh et al., 2019). Oxidative stress occurs when the production of reactive oxygen species overwhelms the antioxidant defence mechanisms leading to cellular damage (Singh et al., 2019). There is an emerging interest in the use of naturally occurring antioxidants for their therapeutic properties. Particularly, phenolics are considered as potential therapeutic agents against a wide range of ailments including neurodegenerative diseases, cancer, diabetes, cardiovascular dysfunction, inflammatory diseases and in ageing (Shahidi and Yeo, 2018). In recent years, the importance of antioxidant activities of phenolic compounds and their potential usage as functional foods and nutraceuticals are being promoted and some 
Table 2. $\mathrm{IC}_{50}$ values $(\mu \mathrm{M})$ on the inhibitory effect of selected phenolic acids (caffeic, ferulic, chlorogenic and $p$-coumaric acids) on Fe ${ }^{2+}$-induced TBARS production in isolated rat brain homogenates as well as their radical scavenging ability against DPPH and ABTS radicals

\begin{tabular}{lllll}
\hline & Caffeic Acid & Ferulic Acid & Chlorogenic Acid & $p$-coumaric Acid \\
\hline TBAS Production & $14.85 \pm 0.12^{\mathrm{b}}$ & $81.38 \pm 0.04^{\mathrm{d}}$ & $7.54 \pm 6.42^{\mathrm{a}}$ & $32.61 \pm 2.87^{\mathrm{c}}$ \\
DPPH scavenging ability & $91.73 \pm 1.70^{\mathrm{d}}$ & $79.42 \pm 1.59^{\mathrm{c}}$ & $10.33 \pm 8.89^{\mathrm{a}}$ & $20.30 \pm 3.01^{\mathrm{b}}$ \\
ABTS scavenging ability* & $8.72 \pm 0.07^{\mathrm{b}}$ & $13.88 \pm 0.06^{\mathrm{c}}$ & $7.211 \pm 0.06^{\mathrm{a}}$ & $63.07 \pm 0.06^{\mathrm{d}}$ \\
\hline
\end{tabular}

Values represent means \pm standard deviation $(n=3) .{ }^{\text {a-d }}$ Mean values with the same superscript letter on the same row are not significantly different $(p>0.05) .{ }^{*} \mu$ mol. Trolox Antioxidant Equivalent.

evidence suggests that the biological actions of these compounds are related to their antioxidant activity (Adefegha, 2018). Phenolic acids behave as antioxidants, due to the reactivity of the hydroxyl substituent on the aromatic ring. Although there are several mechanisms, the predominant mode of antioxidant activity for these compounds is believed to be via radical scavenging. Also, their antioxidant activity seems to be related to their molecular structure, more precisely to the presence and number of hydroxyl groups, and to double bond conjugation and resonance effects (Rice-Evans et al., 1996).

The effect of free radical on brain can be detected through the elevated level of TBARS content. In this study, the phenolic acids inhibited $\mathrm{Fe}^{2+}$ induced TBARS production in rat brain homogenate with chlorogenic acid having the highest inhibitory effect. This inhibition of $\mathrm{Fe}^{2+}$ induced lipid peroxidation in brain homogenate by the phenolic compounds is consistent with the findings of Oboh et al. (2010) and reaffirms the protective roles of phenolic acids in the protection of brain tissue against oxidative assault and consequent neurodegeneration

Furthermore, chlorogenic acid is shown to have the highest DPPH radical and ABTS cation scavenging abilities. This could be attributed to the higher number of available hydroxyl $(\mathrm{OH})$ groups of the chlorogenic acid molecule compared with other phenolic acids used for this study. Based on structure-activity relationships, the high radical-scavenging activity of chlorogenic acid may be related to the number of hydroxyl group on its aromatic ring (Berlin et al., 2006). Polyphenols are thought to display their antioxidant capacity, depending on the hydroxylation status of their aromatic rings (De Kok et al., 2008). The antioxidant foremost mechanism of action is assumed to be through its radical-scavenging activity that is linked to their hydrogen- or electron-donating ability and to the stability of the resulting phenoxyl radicals (Nguyen et al., 2003). The ability of the phenolic acids to scavenge free radicals and inhibit TBAS production in this study further reinforces their antioxidant properties. Indeed the DPPH radical and ABTS cation scavenging assay not only suggest the in vitro antioxidant properties of a substance but has been shown to correlate to its cellular antioxidant properties (Falcão et al., 2019). Moreover, recent studies have revealed that polyphenols are able to cross blood brain barrier and show neuroprotection against free radical damage (Martin et al., 2011; Nguyen et al., 2003).

\section{Conclusion}

Altered purinergic signaling has been the central focus of many neurodegenerative diseases with deranged ATP homoeostasis underlying many diseases of the central nervous system. However, the observed modulatory effect of the enzymes of the purinergic system by the phenolic acids suggests possible interaction critical to neuroprotection. These coupled with the potent antioxidant properties of the phenolic acids as evidenced by this study makes this group of phytochemicals an interesting source of compounds for the development of drugs which protects and improves brain functions.

\section{References}

Adefegha, S.A. (2018). Functional foods and nutraceuticals as dietary intervention in chronic diseases; novel perspectives for health promotion and disease prevention. J. Dietary Suppl. 15: 977-1009.

Ademiluyi, A.O., Ogunsuyi, O.B., and Oboh, G. (2016). Alkaloid extracts from Jimson weed (Datura stramonium L.) modulate purinergic enzymes in rat brain. Neurotoxicol. 56: 107-117.

Berlin, A., Balakshin, M., Gilkes, N., Kadla, J., Maximenko, V., Kubo, S., and Saddler, J. (2006). Inhibition of cellulase, xylanase and $\beta$-glucosidase activities by softwood lignin preparations. J. Biotechnol. 125: 198209.

Blokland, A., Schreiber, R., and Prickaerts, J. (2006). Improving memory: A role for phosphodiesterases. Curr. Pharm. Des. 12: 2511-23.

Burnstock, G. (2007). Physiology and pathophysiology of purinergic neurotransmission. Physiol. Rev. 87: 659-797.

Celli, G.B., and de Camargo, A.C. (2019). What is in a "Cup of Joe"? From green beans to spent grounds: a mini-review on coffee composition and health benefits. J. Food Bioact. 6: 62-67.

Cilliers, J.J.L., and Singleton, V.L. (1990). Caffeic acid autoxidation and the effects of thiols. J. Agric. Food Chem. 38: 1789-1796.

Crozier, A.A., Jaganath, I.B., and Clifford, M.N. (2009). Dietary phenolics: chemistry, bioavailability and effects on health. Nat. Prod. Rep. 26: 1001-1043.

De Kok, T.M., Van Breda, S.G., and Manson, M. (2008). Mechanism of combined action of different chemopreventive dietary compounds: a review. Eur. J. Nutr. 47: 51-9.

de Lores Arnaiz, G.R., and Ordieres, M.G.L. (2014). Brain Na+, K+-ATPase activity in aging and disease. Int. J. Biomed. Sci. IJBS 10: 85.

Devan, B.D., Bowker, J.L., Duffy, K.B., Bharati, I.S., Jimenez, M., SierraMercado Jr, D., Nelson, C.M., Spangler, E.L., and Ingram, D.K. (2006). Phosphodiesterase inhibition by sildenafil citrate attenuates a maze learning impairment in rats induced by nitric oxide synthase inhibition. Psychopharmacol. 183(4): 439-445.

Falcão, H.G., Silva, M.B., de Camargo, A.C., Shahidi, F., Franchin, M., Rosalen, P.L., Alencar, S.M., Kurozawa, L.E., and Ida, E.I. (2019). Optimizing the potential bioactivity of isoflavones from soybeans via ultrasound pretreatment: Antioxidant potential and NF-KB activation. J. Food Biochem. 23: e13018.

Fiske, C.H., and Subbarow, Y. (1925). The colorimetric determination of phosphorus. J. of Biol. Chem. 66: 375-400.

Gawlik-Dziki, U., Dziki, D., Świeca, M., and Nowak, R. (2017). Mechanism of action and interactions between xanthine oxidase inhibitors derived from natural sources of chlorogenic and ferulic acids. Food Chem. 225: 138-145.

Goding, J.W. (2000). Ecto-enzymes: physiology meets pathology. J. Leukoc. Biol. 67: 285-311.

Guieu, R., Dussol, B., Halimi, G., Bechis, G., Sampieri, F., Berland, Y., Sampol, J., Couranud, F., and Rochat, H. (1998). Adenosine and the nervous system: pharmacological data and therapeutic perspectives. Gen. Pharmacol. 31: 553-561.

Gyamfi, M.A., Yonamine, M., and Aniya, Y. (1999). Free-radical scaveng- 
ing action of medicinal herbs from Ghana, Thonningia sanguine on experimentally induced liver injuries. Gen. Pharmacol. 32: 661-667.

Heymann, D., Reddington, M., and Kreutzberg, G.W. (1984). Subcellular localization of 5'-nucleotidase in rat brain. J. Neurochem. 43: 971-978.

Ishisaka, A., Ichikawa, S., Sakakibara, H., Piskula, M.K., Nakamura, T., and Kato, Y. (2011). Accumulation of orally administered quercetin in brain tissue and its antioxidative effects in rats. Free Radic. Biol. Med. 51: 1329-133.

Jorgensen, P.L., and Pedersen, P.A. (2001). Structure-function relationships of $\mathrm{Na}^{+}, \mathrm{K}^{+}$-ATPase or $\mathrm{Mg}^{2+}$ binding and energy transduction in $\mathrm{Na}, \mathrm{K}$ ATPase. Biochim. Biophys. Acta, Bioenerg. 1505(1): 57-74.

Kelly, S.J., and Butler, L.G. (1977). Enzymic hydrolysis of phosphonate esters. Reaction mechanism of intestinal 5'-nucleotide phosphodiesterase. Biochem. 16(6): 1102-1104.

Koçak-Toker, N., Aktan, G., and Aykaç-Toker, G. (2002). The role of Na, KATPase in human sperm motility. Int. J. Androl. 25: 180-5.

Kumari, D., Chandrasekara, A., and Shahidi, F. (2019). Bioaccessibility and antioxidant activities of finger millet food phenolics. J. Food Bioact. 6: 100-109.

Martin, S., Gonzalez-Burgos, E., Carretero, M., and Gomez-Serranillos, M.P. (2011). Neuroprotective properties of spanish red wine and its isolated polyphenols on astrocytes. Food Chem. 128(1): 40-48.

Nguyen, T., Sherratt, P.J., and Pickett, C.B. (2003). Regulatory mechanisms controlling gene expression mediated by the antioxidant response element. Ann. Rev. Pharmacol. Toxicol. 43(1): 233-260.

Oboh, G., Agunloye, O.M., Akinyemi, A.J., Ademiluyi, A.O., and Adefegha, S.A. (2013). Comparative study on the inhibitory effect of caffeic and chlorogenic acids on key enzymes linked to Alzheimer's disease and some pro-oxidant induced oxidative stress in rats' brain-in vitro. Neurochem. Res. 38: 413-419.

Oboh, G., Akinyemi, J.A., and Ademiluyi, A.O. (2010). Antioxidant and inhibitory effect of red ginger and white ginger on $\mathrm{Fe}^{2+}$ induced lipid peroxidation in rat brain in vitro. Exp. Toxicol Pathol. 64: 31-36.

Ohkawa, H., Ohishi, N., and Yagi, K. (1979). Assay for lipid peroxides in animal tissues by thiobarbituric acid reaction. Ann. Biochem. 95: 351-358.

Pei, K., Ou, J., Huang, J., and Ou, S. (2016). p-Coumaric acid and its conjugates: dietary sources, pharmacokinetic properties and biological activities. J. Sci. Food Agric. 96: 2952-2962.

Prickaerts, J., van Staveren, W.C., and Sik, A. (2002). Effects of two selective phosphodiesterase type 5 inhibitors, sildenafi I and vardenafi I, on object recognition memory and hippocampal cyclic GMP levels in the rat. Neurosci. 113: 351-61.

Puzzo, D., Staniszewski, A., Deng, S.X., Privitera, L., Leznik, E., Liu, S., Zhang, H., Feng, Y., Palmeri, A., Landry, D.W., and Arancio, O. (2009). Phosphodiesterase 5 inhibition improves synaptic function, memory, and amyloid-beta load in an Alzheimer's disease mouse model. J. Neurosci. 29(25): 8075-8086.

Re, R., Pellegrini, N., Proteggente, A., Pannala, A., Yang, M., and Rice-Evans, C. (1999). Antioxidant activity applying an improved ABTS radical cationdecolorisation assay. Free Radic. Biol. Med. 26: 1231-1237.
Reffelman, T., and Kloner, R.A. (2003). Therapeutic potential of phosphodiesterase 5 inhibition for cardiovascular disease. Circulation. 108: 239-244.

Rice-Evans, C.A., Miller, N.J., and Paganga, G. (1996). Structure-antioxidant activity relationships of flavonoids and phenolic acids. Free Rad. Biol. Med. 20: 933-956.

Rico, E.P., Rosemberg, D.B., Senger, M.R., Arizi, M.B., Dias, R.D., Souto, A.A., Bogo, M.R., and Bonan, C.D. (2008). Ethanol and acetaldehyde alter NTPDase and 5'-nucleotidase from zebrafish brain membranes. Neurochem. Int. 52: 290-296.

Rutten, K., Prickaerts, J., and Hendrix, M. (2007). Time-dependent involvement of CAMP and CGMP in consolidation of object memory: studies using selective phosphodiesterase type 2, 4 and 5 inhibitors. Eur. J. Pharmacol. 558: 107-12.

Rutten, K., Vente, J.D., and Sik, A. (2005). The selective PDE5 inhibitor sildenafi I, improves object memory in Swiss mice and increases cGMP levels in hippocampal slices. Behav. Brain Res. 164: 11-16.

Schetinger, M.R.C., Porto, N.M., Moretto, M.B., Morsch, V.M., da Rocha, J.B.T., Vieira, V., Moro, F., Neis, R.T., Bittencourt, S., Bonacorso, H.G., and Zanatta, N. (2000). New benzodiazepines alter acetylcholinesterase and ATPDase activities. Neurochem. Res. 25(7): 949-955.

Sebastián-Serrano, Á., de Diego-García, L., Henshall, D.C., Engel, T., and Díaz-Hernández, M. (2018). Haploinsufficient TNAP Mice Display Decreased Extracellular ATP Levels and Expression of Pannexin-1 Channels. Frontiers Pharmacol. 9: 170.

Senzaki, H., Smith, C.J., and Juang, C.J. (2001). Cardiac phosphodiesterase 5 (cGMP-specific) modulates b-adrenergic signaling in vivo and is down-regulated in heart failure. FASEB J. 15: 1718-1726.

Shahidi, F., and Yeo, J. (2018). Bioactivities of phenolics by focusing on suppression of chronic diseases: A review. Int. J. Mol. Sci. 19: 1573.

Shahidi, F., Vamadevan, V., Oh, W.Y., and Peng, H. (2019). Phenolic compounds in agri-food by-products, their bioavailability and health effects. J. Food Bioact. 5: 57-119.

Singh, A., Kukreti, R., Saso, L., and Kukreti, S. (2019). Oxidative stress: A key modulator in neurodegenerative diseases. Mol. 24: 1583.

Sinha, P., Paswan, R.K., Kumari, A., Kumar, S., Bimal, S., Das, P., and Lal, C.S. (2016). Magnesium-Dependent Ecto-ATP Diphosphohydrolase Activity in Leishmania donovani. Current Microbiol. 73: 811-819.

Soderling, S.H., Bayuga, S.J., and Beavo, J.A. (1999). Isolation and characterization of a dual substrate phosphodiesterase gene family: PDE 10A. Proc. Natl. Acad. Sci. USA 96: 7071-7076.

Wyse, A.T., Streck, E.L., Barros, S.V., Brusque, A.M., Zugno, A.I., and Wajner, M. (2000). Methylmalonate administration decreases $\mathrm{Na}+, \mathrm{K}+-$ ATPase activity in cerebral cortex of rats. Neurorep. 11: 2331-2334.

Yuasa, K., Kotera, J., and Fujishige, K. (2000). Isolation and characterization of two novel phosphodiesterase PDE $11 \mathrm{~A}$ variants showing unique structure and tissue specific expression. J. Biol. Chem. 275: 3146931479.

Zimmermann, H. (2006). Nucleotide signaling in nervous system development. Pflugers Arch. 452: 573-588. 